\title{
Medical device technologies: Who is the user?
}

\section{Syed Ghulam Sarwar Shah ${ }^{1}$, Ian Robinson}

Centre for the Study of Health and Illness, School of Social Sciences, Brunel University, Uxbridge, Middlesex, UB8 3PH, UK

\begin{abstract}
A myriad of medical devices deployed by many users play an essential role in healthcare, and they, and their users, need to be defined, classified and coded effectively. This study provides definitions of terms frequently employed to describe the users of medical device technologies (MDT) as well as a classification of such users. Devices are widely used, developed and assessed by many others than clinicians. Thus, users of medical devices need to be classified in various relevant ways, such as primary and secondary users; user groups such as healthcare professionals, patients, carers, persons with disabilities, those with special needs, as well as professionals allied with healthcare. Proper definition and classification of MDT users is particularly important for integrating the users' perspectives in the process of MDT development and assessment, as well as in relation to the regulatory, health and safety, and insurance perspectives concerning MDT.
\end{abstract}

Keywords: Medical devices, User, Classification; Healthcare; Technology; Taxonomy, User perspective.

\section{Introduction}

Despite protestations that healthcare has always been user-centred, which in a general and obvious sense is true, recently it has become far more explicit that directly involving many different types of users, and particularly end-users, at all stages of healthcare is crucial in the developmental and monitoring process. User involvement in healthcare services design and provision (Allsop and Taket, 2003), as well as in the medical device technology development and assessment (MDTD\&A) process (Shah and Robinson, 2006), has become a touchstone of enlightened practice. As an important issue, it is said to be because users are the ultimate beneficiaries of such developments in everyday settings, and as a result there is no-one who can better judge the continuous operational performance of the device concerned, and recount any problems encountered in its use (World Health Organization, 2003).

In addition, users, who are now formally designated as customers (Rowley, 2000) or consumers (Mackay et al., 2000), have heightened expectations that not only services and products, including medical devices, that they buy will meet their particular needs, but that they should also have had a major role in their development (Poolton and Ismail, 2000). Therefore, a detailed engagement with users, and a formal assessment as well as fulfilment of their needs are important elements of modern product development (Brockhoff, 2003). This is even more true in the case of medical device technologies (MDT) because the position of users in relation to devices allows them to

${ }^{1}$ Corresponding author

E-mail: Sarwar.Shah@brunel.ac.uk 
Reference to this paper should be made as follows: Shah, S.G.S. and Robinson, I. (2008) 'Medical device technologies: who is the user?', Int. J. Healthcare Technology and Management, Vol. 9, No. 2, pp.181-197. DOI: 10.1504/IJHTM.2008.017372 [Note: This is pre-published version of the paper]

better judge the performance of the device concerned, than perhaps the performance of many pharmaceutical products, and thus isolate problems encountered in its use (World Health Organization, 2003). Increasing evidence shows that continuously interacting with medical device users and taking account of their needs from an early stage during the development and evaluation process results in the production of most successful and long lasting medical devices (Shaw, 1985; Brockhoff, 2003; Wai and Siu, 2003). However, conversely, ignoring user views may lead to the failure of MDT to meet user needs, and thus can result in under use or even rejection (Gallivan and Keil, 2003), having serious repercussions (Stone and McCloy, 2004), including a range of fundamental developmental errors (Kaye and Crowley, 2000; Food and Drug Administration, 2003; Ward and Clarkson, 2004). Such errors are not only important in terms of a device not being appropriately geared to users' perspectives (Samore et al., 2004), but are also, even more seriously, frequent causes of preventable injury and mortality (Nobel, 1996; Lin, 1998; Amoore and Ingram, 2002; Baker et al., 2004; Bennett et al., 2005). Thus, emphasising user involvement and the incorporation of user perspectives, provides a clear rationale for risk avoidance and the associated necessary management strategies (World Health Organization, 2003; Small, 2004).

Thus tackling the relationship between the user and the device, amongst other things, requires the incorporation of users' perspectives directly in the MDTD\&A process, which implies detailed information about users themselves, as well as their subsequent direct involvement (Thoren, 1996). Nevertheless, comprehensive and useful information about users of MDT can only be obtained, when they are properly defined, identified and classified. This no trivial problem, bearing in mind the variety of users, the variety of devices and the almost infinite range of settings in which devices may be deployed.

In addition, given the crucial role that the increasing numbers, types and complexity of medical devices play in the healthcare industry, MDT manufacturers across the globe are thus engaged in a continual search for the most appropriate ways in which user parameters can best be deployed in the design, development and assessment process. Given the enormous variety, categories and utilities of medical devices internationally, there have been a wide range of attempts to define and classify them in different countries and regions of the world (Health Canada, 1985; Australian Government, 1989; Therapeutic Goods Administration, 1989; European Community, 1990;1993;1994; HMSO, 1994;1995; Food and Drug Administration, 1997; European Community, 1998; Health Canada, 1998; HMSO, 2000; European Community, 2001; Industry Canada, 2001; Swissmedic, 2001a;2001b; Australian Government, 2002; HMSO, 2002; Department of Health, 2003; World Health Organization, 2003). In this process, there have been major attempts to construct useful taxonomies as medical devices have been categorised, coded and standardised (Food and Drug Administration, 2001; Global Medical Device Nomenclature, 2003; Food and Drug Administration, 2004; Newapproach, 2004).

Given the huge and widening portfolio of medical devices, a similarly widening range of their users has developed, which includes doctors, nurses, patients, family members and relatives of patients, and often a large number of professional caregivers and other professionals allied to healthcare (Kaye and Crowley, 2000; Swissmedic, 2001c; Department of Health, 2003; Therapeutic Goods Administration, 2003). However, despite this exponential increase in 'users', they have not been defined and classified in a formal way which would assist in the tailoring of products for particular user communities, as well avoiding increasing confusion as to who is the 'user' and how a device or product might best be developed for them.

The aims of this study then are to define, identify and classify users of MDT. However, rather than trying to develop a taxonomy for each device, the strategy of the analysis is to provide a more generic classification. The objectives of this paper then are to provide answers to the following questions:

- what does a user of a medical device mean?

- $\quad$ is there an accepted universal definition of the term medical device user?

- who are the users of MDT?

- what are the classes and types of MDT users?

- $\quad$ which types of MDT users are involved in MDTD\&A?

- is there an accepted taxonomy of MDT users?

- what should be an acceptable conceptual taxonomy of MDT users?

- what are the implications of MDT user classification? 
Reference to this paper should be made as follows: Shah, S.G.S. and Robinson, I. (2008) 'Medical device technologies: who is the user?', Int. J. Healthcare Technology and Management, Vol. 9, No. 2, pp.181-197. DOI: 10.1504/IJHTM.2008.017372 [Note: This is pre-published version of the paper]

In this paper, medical device technologies include medical devices and assistive technology devices and we therefore use the widely accepted definition of 'medical device' employed by the Global Harmonisation Task Force (World Health Organization, 2003) and the definition of 'assistive technology device' as given in relevant legislation (Government of USA, 1998).

\section{Methodology}

This study comprises a structured review of relevant published literature, and from this review, a novel conceptual framework is developed.

The Engineering and Physical Sciences Research Council (EPSRC) funded MATCH (Multidisciplinary Assessment of Technology Centre for Healthcare) (MATCH, 2006) which included a commissioned review of published literature on user involvement in MDTD\&A in three academic disciplines that is healthcare, engineering and ergonomics, and social sciences. Bridgelal Ram et al (2005) and Martin et al (2006) reviewed the healthcare, and engineering and ergonomic literatures respectively.

Table 1 List of keywords used for literature searches

\begin{tabular}{|l|}
\hline Assistive devices \\
Classification \\
Device users \\
Device developers \\
End-users \\
Focus groups \\
Innovation research \\
Innovative processes \\
Innovative product design \\
Healthcare technology \\
Medical device \\
Medical device design \\
Medical device technology \\
Medical device users \\
Needs assessment \\
Needs assessment tools \\
New medical technology \\
Participatory design \\
Questionnaire based survey \\
Requirement analysis \\
Taxonomy \\
Technological innovation \\
User centred product design \\
User criteria \\
User definition \\
User engagement methods \\
User input \\
User interests \\
User involvement \\
User needs \\
User needs assessment \\
User participation \\
User perceptions \\
User perspective \\
User requirements elicitation \\
User studies \\
User survey \\
\hline
\end{tabular}

We conducted an extensive structured review of social science literature between January 2004 and April 2005 to understand the particular ways in which users have been central to the process of MDTD\&A. 
Reference to this paper should be made as follows: Shah, S.G.S. and Robinson, I. (2008) 'Medical device technologies: who is the user?', Int. J. Healthcare Technology and Management, Vol. 9, No. 2, pp.181-197. DOI: 10.1504/IJHTM.2008.017372 [Note: This is pre-published version of the paper]

We extracted information in four defined categories:

- $\quad$ the types of users involved in MDTD\&A

- the types of devices developed and assessed by user involvement

- $\quad$ the methods used for engagement with users for MDTD\&A

- $\quad$ the stages of the medical device lifecycle in which users were involved.

We adapted the literature review process from the frameworks proposed by Beverley et al. (2004) and Bruce and Mollison (2004). Criteria for the inclusion of studies in the review were that they were published in English language peer reviewed journals and peer reviewed conference contributions from 1980 to 2005 describing user involvement in the development and assessment of new and redesigned medical devices; the contributions may relate to any country. Studies for the same period seeking to capture user needs and describing user involvement in the product development process were also reviewed. Studies were excluded if they did not involve any type of users in MDTD\&A process (however broadly defined)) or were theoretical rather than empirical in nature.

We prepared and used a list of 37 key words (Table 1) for searching different electronic bibliographic databases, which included Blackwell Synergy, EBSCOhost, Emerald, Inderscience, Ingenta, International Bibliography of the Social Sciences (IBSS), JSTOR, Kluwer, Medical Device Link, ProQuest, SAGE, ScienceDirect, Social Science Information Gateway (Sosig), SpringerLink, Taylor \& Francis, and ZETOC.

We identified 556 articles by selecting their titles. Reading abstracts of the articles, we shortlisted studies that fulfilled the inclusion criteria for full review. A research fellow and two social science PhD students reviewed 418 full articles independently and extracted information to a spreadsheet template developed in-house. Twenty-eight of the articles were reviewed by two different reviewers. The abstracted information was independently assessed and found to be remarkably consistent in its extraction, which confirmed the reliability of the literature review process and the criteria that were used to abstract the information.

\section{$3 \quad$ Results}

The findings of the literature review, particularly in relation to the methods used for engagement with users, the types of medical devices developed through user involvement and the stages of the medical device lifecycle during which users were involved, have been reported elsewhere (Shah and Robinson, 2006). Nonetheless, the unpublished and detailed information about types of MDT users involved in MDTD\&A, and the novel conceptual work with associated classifications is presented in this paper.

The results show that twenty-nine studies reported the involvement of various types of MDT users in the process of MDTD\&A (Table 2). We found that clinicians, as might be surmised, are not the only users of MDT; devices are also being widely used, developed and assessed by many others, ranging from patients and persons with disabilities, to carers, to many different types of professional staff allied to healthcare. This suggests that MDT users are not a homogenous group but have a great deal of heterogeneity, and use MDT from radically different perspectives. Furthermore, they are different from each other in several additional respects; hence, they could be defined differently in relation to their MDT usage by virtue of being in different classes, groups and types.

We found that none of the reviewed studies reported any operational definition or classification of MDT users in a formal and meaningful way. In many respects 'user' or 'users' were seen as self evident categories, in studies with totally different aims, objectives or structure, which appeared to require no further explanation. This state of affairs is very concerning for it appears that development or monitoring may be undertaken using different (but un-stated) baselines, and conclusions drawn about comparative value without the necessary formal criteria. 
Reference to this paper should be made as follows: Shah, S.G.S. and Robinson, I. (2008) 'Medical device technologies: who is the user?', Int. J. Healthcare Technology and Management, Vol. 9, No. 2, pp.181-197. DOI: 10.1504/IJHTM.2008.017372 [Note: This is pre-published version of the paper]

Table 2 Types of MDT users involved in the MDTD\&A process

\begin{tabular}{|c|c|c|c|}
\hline Study/Author(s) & Year & Types of users involved & $\begin{array}{l}\text { MDT developed / } \\
\text { assessed }\end{array}$ \\
\hline Batavia and Hammer & $(1990)$ & Persons with different disabilities & Assistive device \\
\hline Brooks & (1991) & Persons with disabilities & Assistive devices \\
\hline Buhler at al. & (1995) & Persons with different disabilities & Wheel chairs \\
\hline Buhler & (1996) & Persons with different disabilities & $\begin{array}{l}\text { Robotic aids and } \\
\text { wheel chairs }\end{array}$ \\
\hline Obradovich and Woods & (1996) & Nurses & Infusion pump \\
\hline Handels et al. & (1997) & $\begin{array}{l}\text { Physicians, neurosurgeons, } \\
\text { radiologists, } \mathrm{CT}^{*} \text { and } \mathrm{MRI}^{* *} \\
\text { professionals }\end{array}$ & Teleradiology system \\
\hline Lin et al. & (1998) & Nurses & $\begin{array}{l}\text { Patient controlled } \\
\text { analgesia pump }\end{array}$ \\
\hline Shaw & (1998) & Clinicians & $\begin{array}{l}\text { Different medical } \\
\text { equipments }\end{array}$ \\
\hline Woodside et al. & (1998) & Carers & Syringes \\
\hline Craig et al. & (1999) & $\begin{array}{l}\text { Patients with neurological problems, } \\
\text { neurologist, physician and other } \\
\text { medical staff }\end{array}$ & Teleneurology \\
\hline Friedrich & (1999) & Dermatologist & $\begin{array}{l}\text { Electronic } \\
\text { luminescence } \\
\text { microscope }\end{array}$ \\
\hline Bray & $(2000)$ & Blood parameter monitor users & $\begin{array}{l}\text { Blood parameter } \\
\text { monitor }\end{array}$ \\
\hline Hasu and Engestrom & $(2000)$ & $\begin{array}{l}\text { Doctor, nurse and clinical } \\
\text { neurophysiologist }\end{array}$ & Neuromagnetometer \\
\hline Hasu & $(2000)$ & Doctor, nurse and patient & Neuromagnetometer \\
\hline Mulholland et al. & $(2000)$ & $\begin{array}{l}\text { Persons with bilateral lower } \\
\text { extremity disabilities }\end{array}$ & $\begin{array}{l}\text { Wheeled mobility } \\
\text { devices }\end{array}$ \\
\hline Hummel et al. & (2001) & Cardiologist and cardio-surgeon & $\begin{array}{l}\text { Intraventricular } \\
\text { blood pump }\end{array}$ \\
\hline Lacey and Selvin & (2001) & Persons with visual impairments & $\begin{array}{l}\text { Robotic walking } \\
\text { frame (walker) }\end{array}$ \\
\hline Lin et al. & (2001) & Nurses & $\begin{array}{l}\text { Patient controlled } \\
\text { analgesia pump }\end{array}$ \\
\hline Samuelsson et al. & (2001) & $\begin{array}{l}\text { Persons with spinal cord injury, } \\
\text { multiple sclerosis, stroke, cerebral } \\
\text { palsy, spina bifida and mental } \\
\text { disability }\end{array}$ & Wheel chairs \\
\hline Staccini et al & $(2001)$ & $\begin{array}{l}\text { Staff working in blood transfusion } \\
\text { unit }\end{array}$ & $\begin{array}{l}\text { Clinical information } \\
\text { system }\end{array}$ \\
\hline Anderson & (2002) & $\begin{array}{l}\text { Patients (asthmatic), general } \\
\text { practitioners, nurses, carers and }\end{array}$ & Inhaler \\
\hline
\end{tabular}


Reference to this paper should be made as follows: Shah, S.G.S. and Robinson, I. (2008) 'Medical device technologies: who is the user?', Int. J. Healthcare Technology and Management, Vol. 9, No. 2, pp.181-197. DOI: 10.1504/IJHTM.2008.017372 [Note: This is pre-published version of the paper]

pharmacists

Garmer et al.

Garmer et al.

Hummel et al.

Kittel et al.

Miettinen and Hasu

Stickle et al.

Garmer et al.

Liljegren and Osvalder (2002a) Nurses

(2002b) Nurses

Physicians and person with

laryngectomy

Persons with spinal cord injury

Surgeons, clinical neurophysiologist, nurse and medical physicist

Persons with degenerative neuromuscular conditions

Nurses
Infusion pump

Infusion pump

Voice-producing

prosthesis

Wheel chairs

Neuromagnetometer

Powered wheel

chairs

Ventilator

Patient monitoring system

${ }^{*} \mathrm{CT}=$ Computerised Tomography, ${ }^{* *} \mathrm{MRI}=$ Magnetic Resonance Imaging (Ehrlich and Schroeder, 2004).

To investigate further, we consulted legislation on MDT such as that embodied in Australian (Australian Government, 2002), Canadian (Health Canada, 1998), the European Union (European Community, 1990;1993;1994;1998), the United Kingdom (HMSO, 1994;1995;2000;2002) and the United States (Food and Drug Administration, 1997) regulations but found no clear definition and classification of MDT users. However, "patients" and "users" were generally mentioned as separate entities in relation to medical devices, which suggest that patients are generally seen as in a different category from the device users, or perhaps they might even be seen as a subset of them. This lack of clarity implies that there is no accepted universal definition of the term 'MDT user', and certainly no classification used, and overall there appears to be, as we have noted before, no accepted taxonomy of MDT users. We therefore attempted to define and classify users of MDT as shown in Figure 1.

\section{Definitions and Classification of MDT users}

\subsection{Definitions}

We define a 'medical device user' as 'a person who uses a medical device for the treatment and/or care of him- /her-self or someone else'. The 'end-user' is defined as 'a person who is the ultimate beneficiary of the usage of a medical device and who can also be the user of medical device if using the medical device for him- /her-self'.

Thus, there can be more than one type of user involved in the use of a medical device and indeed, there can be both professionals and laypersons involved. For instance, in the case of a surgeon putting an implant into the body of a patient, the surgeon will be the 'user' and the patient will be the 'end-user'. In some cases, the 'user' and the 'end-user' may be the same person, as in the case of a patient with diabetes mellitus using a glucometer to check his/her sugar level or a person with a mobility disability using a wheel chair.

\subsection{Classification}

We suggest a helpful classification of medical device users could be as in Figure 1, in which we have divided medical device users into two classes, seven groups and several types and sub-types. We have classified MDT users in-to two classes i.e. primary and secondary, based on the purpose of the usage of medical devices. By 'primary users', we mean 'the users who deploy a device for the intended therapeutic use as envisaged by the manufacturer'. The intended use of a device is generally in the direct therapy of a person. We define the 'secondary users' as 'the users who use a device for a purpose other than the direct intended therapeutic use' such as testing, calibration, learning and research. 
Reference to this paper should be made as follows: Shah, S.G.S. and Robinson, I. (2008) 'Medical device technologies: who is the user?', Int. J. Healthcare Technology and Management, Vol. 9, No. 2, pp.181-197. DOI: 10.1504/IJHTM.2008.017372 [Note: This is pre-published version of the paper]

Based on the position of MDT user in a complex healthcare system, we have divided MDT users into seven groups i.e. healthcare professionals (fully qualified), patients, people with special needs (e.g. persons with disabilities or impairments), carers, non-clinical professionals working in healthcare organisations, students and trainees in the clinical / healthcare professions, and researchers.

We have categorised each group of MDT users into different types based on their common personal and professional traits, which can be further divided into sub-types as illustrated in Figure 1.

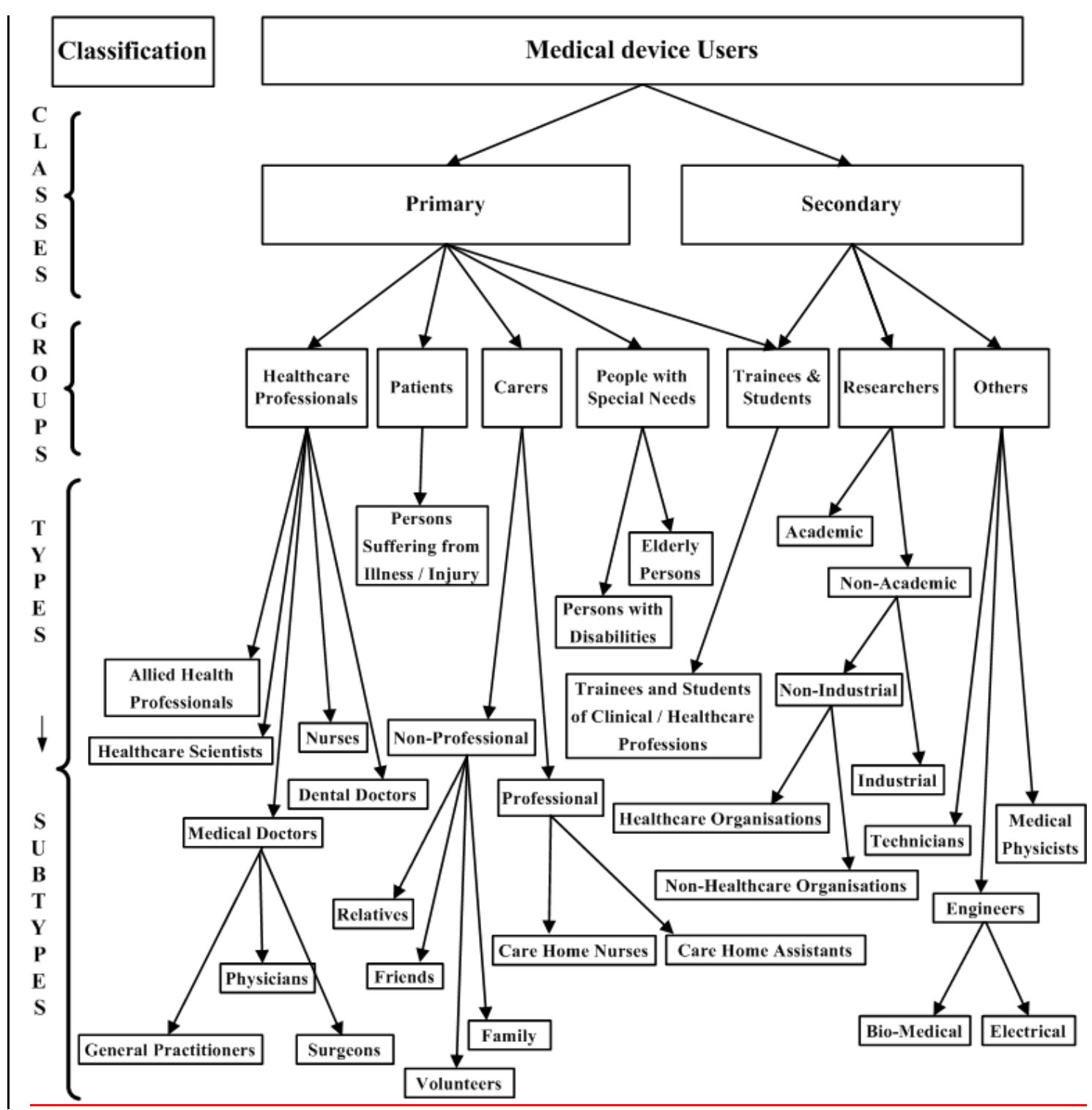

Figure 1 Classification of medical device technology users

\section{Discussion}

This paper shows that users of MDT, who have traditionally been regarded as just healthcare professionals and patients (World Health Organization, 2003), can be further helpfully subdivided depending upon the type of medical device being considered and the place in which the device is being used. For example, whilst many medical devices are of course used in healthcare facilities, increasingly they are used in care homes, private homes and elsewhere (Lehoux et al., 2004; Ward and Clarkson, 2004). 
In the latter case, devices are often used by lay users themselves (World Health Organization, 2003), without direct continuous or immediate clinical supervision. Increasingly therefore, users of medical devices may comprise well trained, semi-trained and even untrained persons, both based on, and leading to sets of needs that vary in nature and degree from employing those devices which are installed, inserted or provided, and then closely and continuously monitored by clinical professionals (Potter-Brotman, 1994; Jones, 1996; Franke and von Hippel, 2002; Beverley et al., 2004). Users of medical device technologies may therefore be increasingly diverse, and include, amongst others, clinicians, patients, professional carers and family members or relatives of patients (Food and Drug Administration, 2003; Therapeutic Goods Administration, 2003) as well as persons having special needs.

Furthermore, the users of medical devices despite being diverse have a common desire in certain key parameters of such devices, i.e. they want safe, effective, reliable and useable medical devices (Kaye and Crowley, 2000). They, being both considered, and considering themselves customers, expect medical devices tailored to their individual and special needs in ways that were not considered as crucial when the sole arbiters of the device were other than the end-users (e.g. previously where a clinician or clinicians was/were the only key judge of effectiveness or quality) (Poolton and Ismail, 2000). Indeed since there are different types of the MDT users, therefore, the range of perspectives in relation to each device may be considerably greater, as well as each user's perspective being different (Teeravarunyou and Sato, 2001). Hence, detailed and timely information of their needs, requirements, preferences and experiences is essential for successful product development (Adams et al., 1998) and in meeting both users' and manufacturers' perspectives appositely (Margolin, 1997; Gerstheimer and Lupp, 2004). A successful product is thus not only the one which is commercially beneficial to the manufacturer (Glen and Lord, 1996) but the one, which is also beneficial to its users. That is it fulfils users' especially end-users' needs and requirements, which we have seen may be complex and possibly even probably different to the needs and requirements of either clinicians or manufacturers. Indeed fulfilling user requirements is crucial to obtaining commercial success. In addition, continuous user involvement is required to develop successful new products (Brockhoff, 2003), which require a high degree of continuing user satisfaction and acceptance (Griffin and Page, 1996) for their long term viability. Evidence shows indeed that dedicated interactions with users and capturing and integrating their knowledge into product development have been found to be generally associated with product success, value and profitability (Shaw, 1985; Biemans, 1991; Gruner and Homburg, 2000; Teeravarunyou and Sato, 2001; Ritter and Walter, 2003). Moreover, reduction of errors and improvement in the safety of end-users also requires that the users of MDT are taken into account during the MDTD\&A process (Buckle et al., 2006).

There is evidence that users are involved in MDTD\&A; however, they are mostly clinicians (Bridgelal Ram et al., 2005; Martin et al., 2006; Shah and Robinson, 2006) who will have only one of the many possible perspectives to bring to MDTD\&A. As we have seen, there are other types of primary users of MDT such as patients, carers, laypersons and people with special needs. Consideration of different types of the primary users will be therefore required in the process of MDTD\&A, for they may vary in their level of training, knowledge, experience and physical and mental abilities (Kaye and Crowley, 2000; Lewis, 2001) and to fulfil their needs, requirements and expectations. Of additional importance their environment, culture, social norms, perceptions and attitudes may also be different (United Nations, 1997). In this regard, an acknowledgement of the diversity of backgrounds, interests and skills of users is essential, as is a formal classification of MDT users such as that presented in this paper.

\section{Implications of MDT user classification}

The classification presented by this paper does not propose a hierarchy among the different groups and types of medical device users discussed here, nor do we intend to suggest watertight compartmentalisation between different groups of the users. There needs, aims and objectives, may indeed overlap.

All types of users are, from our core argument, important in their own right. However, in the developmental process of a device some of them may be more important than others are in relation to particular stages. For example, primary users will be particularly important from device 
Reference to this paper should be made as follows: Shah, S.G.S. and Robinson, I. (2008) 'Medical device technologies: who is the user?', Int. J. Healthcare Technology and Management, Vol. 9, No. 2, pp.181-197. DOI: 10.1504/IJHTM.2008.017372 [Note: This is pre-published version of the paper]

development, assessment and usage perspectives, whereas other types of user may be very important from usage, regulatory, insurance and health and safety perspectives.

Thus, overall we argue that the classification of MDT users presented in this paper is important for its application in development and assessment of MDT itself. It is also crucial from the regulatory, insurance and health and safety perspectives in healthcare.

\section{Conclusion}

It has been assumed by default if not by design that medical device users are in one of two ill-defined generic categories 'clinicians' and 'patients'. Such an approach has led to a narrow two-dimensional approach to users that has belied the richness and complexity of the ways in which, in practice, medical devices are employed in every day use.

As this study has shown, medical device users are heterogeneous and composed of different classes, groups and types. The users, being diverse, have varied needs and requirements. It is therefore imperative to recognise the diversity of medical device users if their perspectives are to be applied to, and integrated into, medical device technologies. Without acknowledging this issue, the development of medical devices will be both less effective and less relevant to the constituencies of users to which they are ostensibly addressed, and just as important will lead to the loss, or foreshortening of commercial opportunities for manufacturers.

In this regard, the definitions and classification of MDT users presented in this paper are particularly important in relation to the process of MDTD\&A and its regulatory, health and safety, and insurance context.

\section{Acknowledgements}

The Multidisciplinary Assessment of Technology Centre for Healthcare (MATCH) program, which is sponsored by the Engineering and Physical Sciences Research Council (EPSRC Grant GR/S29874/01), funded this study, although the views expressed are entirely those of the authors. The authors acknowledge the contributions of John Pappas and Joseph Adonu, PhD students, in reviewing some of the articles during their internship. The authors thank to Professors Clive Seal and Terry Young at Brunel University and two anonymous reviewers for comments on earlier version of the manuscript.

\section{References}

Adams, M. E., Day, G. S. and Dougherty, D. (1998) 'Enhancing new product development performance: an organizational learning perspective', Journal of Product Innovation Management, Vol. 15, No. 5, pp. 403-422.

Allsop, J. and Taket, A. (2003) 'Evaluating user involvement in primary healthcare', International Journal of Healthcare Technology and Management, Vol. 5, No. 1/2, pp. 34-44.

Amoore, J. and Ingram, P. (2002) 'Learning from adverse incidents involving medical devices', BMJ, Vol. 325, No. 7358, pp. 272-275.

Anderson, G. J. M. (2002) 'Shaping the future: using voice of the customer methodology to develop inhaler design', In R. N. Dalby, P. R. Byron, J. Peart and S. J. Farr (Eds) Proceedings of Respiratory Drug Delivery VIII Conference, Tucson, AZ., May 12-16. Raleigh, NC.: Serentec Press, Vol. 1, pp. 179188.

Australian Government (1989) 'Therapeutic Goods Act 1989', Canberra, The Attorney-General's Department, Australian Government, pp. 1-291.

Australian Government (2002) 'Therapeutic Goods (Medical Devices) Regulations 2002', Canberra, The Attorney-General's Department, Australian Government.

Baker, G. R., Norton, P. G., Flintoft, V., Blais, R., Brown, A., Cox, J., Etchells, E., Ghali, W. A., Hebert, P., Majumdar, S. R., O'Beirne, M., Palacios-Derflingher, L., Reid, R. J., Sheps, S. and Tamblyn, R. (2004) 'The Canadian Adverse Events Study: the incidence of adverse events among hospital patients in Canada', CMAJ, Vol. 170, No. 11, pp. 1678-1686. 
Reference to this paper should be made as follows: Shah, S.G.S. and Robinson, I. (2008) 'Medical device technologies: who is the user?', Int. J. Healthcare Technology and Management, Vol. 9, No. 2, pp.181-197. DOI: 10.1504/IJHTM.2008.017372 [Note: This is pre-published version of the paper]

Batavia, A. I. and Hammer, G. S. (1990) 'Toward the development of consumer-based criteria for the evaluation of assistive devices', Journal of Rehabilitation Research and Development, Vol. 27, No. 4, pp. 425-436.

Bennett, C. L., Nebeker, J. R., Lyons, E. A., Samore, M. H., Feldman, M. D., McKoy, J. M., Carson, K. R., Belknap, S. M., Trifilio, S. M., Schumock, G. T., Yarnold, P. R., Davidson, C. J., Evens, A. M., Kuzel, T. M., Parada, J. P., Cournoyer, D., West, D. P., Sartor, O., Tallman, M. S. and Raisch, D. W. (2005) 'The research on adverse drug events and reports (RADAR) project', JAMA, Vol. 293, No. 17, pp. 21312140.

Beverley, C. A., Bath, P. A. and Booth, A. (2004) 'Health information needs of visually impaired people: a systematic review of the literature', Health \& Social Care in the Community, Vol. 12, No. 1, pp. 124.

Biemans, W. G. (1991) 'User and third-party involvement in developing medical equipment innovations', Technovation, Vol. 11, No. 3, pp. 163-182.

Bray, D. D. (2000) 'Creative collaboration: User-centered design in practice', Medical Device \& Diagnostic Industry, No. March, pp. 76-89.

Bridgelal Ram, M., Browne, N., Grocott, P. and Weir, H. (2005) 'DELIVERABLE 6 Methods To Capture User Perspectives in the Medical Device Technology Life Cycle: A Review of the Literature In Health Care, Social Science, and Engineering \& Ergonomics. Part A: Methods to Capture User Perspectives in Medical Device Development: A Review of the Literature in Health Care', Multidisciplinary Assessment of Technology Centre for Healthcare. Available at: http://www.match.ac.uk/ (Accessed 10 March 2006).

Brockhoff, K. (2003) 'Customers' perspectives of involvement in new product development', International Journal of Technology Management, Vol. 26, No. 5/6, pp. 464-481.

Brooks, N. A. (1991) 'User's responses to assistive devices for physical disability.' Social Science \& Medicine, Vol. 32, No. 12, pp. 1417-1424.

Bruce, J. and Mollison, J. (2004) 'Reviewing the literature: adopting a systematic approach', Journal of Family Planning and Reproductive Health Care, Vol. 30, No. 1, pp. 13-16.

Buckle, P., Clarkson, P. J., Coleman, R., Ward, J. and Anderson, J. (2006) 'Patient safety, systems design and ergonomics', Applied Ergonomics, Vol. 37, No. 4, pp. 491-500.

Buhler, C. (1996) 'Approach to the analysis of user requirements in assistive technology', International Journal of Industrial Ergonomics, Vol. 17, No. 2, pp. 187-192.

Buhler, C., Hoelper, R., Hoyer, H. and Humann, W. (1995) 'Autonomous robot technology for advanced wheelchair and robotic aids for people with disabilities', Robotics and Autonomous Systems, Vol. 14, No. 2-3, pp. 213-222.

Craig, J., Russell, C., Patterson, V. and Wootton, R. (1999) 'User satisfaction with realtime teleneurology', Journal of Telemedicine and Telecare, Vol. 5, No. 4, pp. 237-241.

Department of Health (2003) 'EC Medical Devices Directives: Guidance Notes for Manufacturers of Custom-made Devices', London, Medicines and Healthcare Products Regulatory Agency (MHRA), Department of Health, Guidance Document No. 9, pp. 1-12.

European Community (1990) 'Council Directive 90/385/EEC of 20 June 1990 on the approximation of the laws of the Member States relating to active implantable medical devices', Official Journal of the European Community, No. L 189, pp. 17 - 42.

European Community (1993) 'Council Directive 93/42/EEC of 14 June 1993 concerning medical devices', Official Journal of the European Community, No. L 169, pp. 1-51.

European Community (1994) 'Guidelines Relating to the Application of: The Council Directive 90/385/EEC on Active Implantable Medical Devices, The Council Directive 93/42/EEC on Medical Devices', Brussels, The European Commission, DG Enterprise, Directorate G, Unit 4 - Pressure Equipment, Medical Devices, Metrology, Medical Devices: Guidance, Document No. MEDDEV 2. 1/1. pp. 1-7.

European Community (1998) 'Directive 98/79/EC of the European Parliament and of the Council of 27 October 1998 on in vitro diagnostic medical devices', Official Journal of the European Community, No. L 331, pp. 1-37.

European Community (2001) 'Guidelines for the classification of medical devices.' Brussels, The European Commission, DG Enterprise, Directorate G, Unit 4 - Pressure Equipment, Medical Devices, Metrology, Medical Devices: Guidance, Document No. MEDDEV 2.4/1 Rev.8 pp. 1-17. 
Reference to this paper should be made as follows: Shah, S.G.S. and Robinson, I. (2008) 'Medical device technologies: who is the user?', Int. J. Healthcare Technology and Management, Vol. 9, No. 2, pp.181-197. DOI: 10.1504/IJHTM.2008.017372 [Note: This is pre-published version of the paper]

Food and Drug Administration (1997) 'Chapter V - Drugs and Devices. Federal Food, Drug, and Cosmetic Act 1997', Rockville, MD., Department of Health and Human Services, U.S. Food and Drug Administration.

Food and Drug Administration (2001) 'Recognition and Use of Consensus Standards; Final Guidance for Industry and FDA.' Rockville, MD., Center for Devices and Radiological Health, Department of Health and Human Services, U.S. Food and Drug Administration, Guidance Document, pp. 1-7. Available at: http://www.fda.gov/cdrh/ost/guidance/321.pdf (Accessed 10 March 2006).

Food and Drug Administration (2003) 'Why is human factors engineering important for medical devices?' Rockville, MD., U.S. Food and Drug Administration. Available at: http://www.fda.gov/cdrh/humanfactors/index.html (Accessed 10 March 2006).

Food and Drug Administration (2004) 'Standards Database', Rockville, MD., Center for Devices and Radiological Health, Department of Health and Human Services, U.S. Food and Drug Administration. Available at: http://www.accessdata.fda.gov/scripts/cdrh/cfdocs/cfStandards/search.cfm (Accessed 10 March 2006).

Franke, N. and von Hippel, E. (2002) 'Satisfying heterogeneous user needs via innovation toolkits: The case of Apache Security Software', Cambridge, MA., MIT Sloan School of Management, MIT Sloan School Working Paper No. 4341-02, pp. 32.

Friedrich, G. (1999) 'Sustainability and the design process', Proceedings of International Summer Academy on Technology Studies -Technology Studies and Sustainability, Deutschlandsberg, Austria, July 11-16.

Gallivan, M. J. and Keil, M. (2003) 'The user-developer communication process: A critical case study', Information Systems Journal, Vol. 13, No. 1, pp. 37-68.

Garmer, K., Liljegren, E., Osvalder, A.-L. and Dahlman, S. (2002a) 'Application of usability testing to the development of medical equipment. Usability testing of a frequently used infusion pump and a new user interface for an infusion pump developed with a human factors approach', International Journal of Industrial Ergonomics, Vol. 29, No. 3, pp. 145-159.

Garmer, K., Liljegren, E., Osvalder, A.-L. and Dahlman, S. (2002b) 'Arguing for the need of triangulation and iteration when designing medical equipment', Journal of Clinical Monitoring and Computing, Vol. 17, No. 2, pp. 105-114.

Garmer, K., Ylven, J. and MariAnne Karlsson, I. C. (2004) 'User participation in requirements elicitation comparing focus group interviews and usability tests for eliciting usability requirements for medical equipment: A case study', International Journal of Industrial Ergonomics, Vol. 33, No. 2, pp. 85-98.

Gerstheimer, O. and Lupp, C. (2004) 'Needs versus technology--the challenge to design thirdgeneration mobile applications', Journal of Business Research, Vol. 57, No. 12, pp. 1409-1415.

Glen, J. M. W. and Lord, M. (1996) 'New product development processes within the UK medical device industry', Medical Engineering \& Physics, Vol. 18, No. 8, pp. 670-676.

Global Medical Device Nomenclature (2003) 'A Technical Introductory / User Guide for the GMDN Version 2003.1', Global Medical Device Nomenclature (GMDN), available at:

http://www.gmdn.org/GMDN_Technical_2003v2.pdf (Accessed 10 March 2006).

Government of USA (1998) 'Assistive Technology Act of 1998.' Public Law 105-394 - Nov. 13, 1998, Vol. 112 STAT, pp. 3627-3662.

Griffin, A. and Page, A. L. (1996) 'PDMA success measurement project: Recommended measures for product development Success and Failure', The Journal of Product Innovation Management, Vol. 13, No. 6, pp. 478-496.

Gruner, K. E. and Homburg, C. (2000) 'Does customer interaction enhance new product success?' Journal of Business Research, Vol. 49, No. 1, pp. 1-14.

Handels, H., Rinast, E., Busch, C., Hahn, C., Kuhn, V., Miehe, J., Rossmanith, C., Seibert, F. and Will, A. (1997) 'Image transfer and computer-supported cooperative diagnosis', Journal of Telemedicine and Telecare, Vol. 3, No. 2, pp. 103-107.

Hasu, M. (2000) 'Constructing clinical use: An activity-theoretical perspective to implementing new technology', Technology Analysis \& Strategic Management, Vol. 12, No. 3, pp. 369-382.

Hasu, M. and Engestrom, Y. (2000) 'Measurement in action: An activity-theoretical perspective on producer-user interaction', International Journal of Human-Computer Studies, Vol. 53, No. 1, pp. 6189.

Health Canada (1985) 'Food and Drugs Act (R.S. 1985, c. F-27)', Ottawa, Department of Justice, Government of Canada. 
Reference to this paper should be made as follows: Shah, S.G.S. and Robinson, I. (2008) 'Medical device technologies: who is the user?', Int. J. Healthcare Technology and Management, Vol. 9, No. 2, pp.181-197. DOI: 10.1504/IJHTM.2008.017372 [Note: This is pre-published version of the paper]

Health Canada (1998) 'Medical Devices Regulations (SOR/98-282)', Ottawa, Department of Justice, Government of Canada.

HMSO (1994) 'The Medical Devices Regulations 1994.' Norwich, UK., Her Majesty's Stationery Office (HMSO), Statutory Instrument 1994 No. 3017.

HMSO (1995) 'The Active Implantable Medical Devices (Amendment and Transitional Provisions) Regulations 1995.' London, Her Majesty's Stationery Office (HMSO), Statutory Instrument 1995 No. 1671.

HMSO (2000) 'The In Vitro Diagnostic Medical Devices Regulations 2000', Norwich, UK., Her Majesty's Stationery Office (HMSO), Statutory Instrument 2000 No. 1315.

HMSO (2002) 'The Medical Devices Regulations 2002', Norwich, UK., Her Majesty's Stationery Office (HMSO), Statutory Instrument 2002 No. 618.

Hummel, M., van Rossum, W., Omta, O., Verkerke, G. and Rakhorst, G. (2001) 'Types and timing of inter-organizational communication in new product development', Creativity and Innovation Management, Vol. 10, No. 4, pp. 225-233.

Hummel, M. J. M., Rossum, W. v., Verkerke, G. J. and Rakhorst, G. (2002) 'Product design planning with the analytic hierarchy process in inter-organizational networks', R\&D Management, Vol. 32, No. 5, pp. 451-458.

Industry Canada (2001) 'Quality system requirements for medical devices: Reference guide for manufacturers selling medical devices in Europe, Canada and the United States. 2001 version', Ottawa, Industry Canada, Government of Canada, pp. 1-139.

Jones, C. R. (1996) 'Customer satisfaction assessment for "internal" suppliers', Managing Service Quality, Vol. 6, No. 1, pp. 45-48.

Kaye, R. and Crowley, J. (2000) 'Medical device use-safety: Incorporating human factors engineering into risk management.' Rockville, MD., Center for Devices and Radiological Health, Department of Health and Human Services, U.S. Food and Drug Administration, Guidance Document, pp. 1-33, available at: http://www.fda.gov/cdrh/humfac/1497.pdf (Accessed 10 March 2006).

Kittel, A., Marco, A. D. and Stewart, H. (2002) 'Factors influencing the decision to abandon manual wheelchairs for three individuals with a spinal cord injury', Disability and Rehabilitation, Vol. 24, No. $1 / 2 / 3$, pp. 106-114.

Lacey, G. and Slevin, F. (2001) 'Putting the user at the centre of the design process', Abstracts of proceedings of International Conference on Technology and Aging, Toronto, ON., Canada, September 12-14, pp. 65.

Lehoux, P., Saint-Arnaud, J. and Richard, L. (2004) 'The use of technology at home: what patient manuals say and sell vs. what patients face and fear', Sociology of Health and IIIness, Vol. 26, No. 5, pp. 617-644.

Lewis, C. (2001) 'Emerging trends in medical device technology: Home is where the heart monitor is', FDA Consumer, Vol. 35, No. 3 (May-June), available at:

http://www.fda.gov/fdac/features/2001/03_home.html (accessed 10 March 2006).

Liljegren, E. and Osvalder, A.-L. (2004) 'Cognitive engineering methods as usability evaluation tools for medical equipment', International Journal of Industrial Ergonomics, Vol. 34, No. 1, pp. 49-62.

Lin, L. (1998) 'Human error in patient-controlled analgesia: Incident reports and experimental evaluation.' Proceedings of the 42nd Annual Meeting 'Human Factors and Ergonomics Society', Santa Monica, CA., October 5-9, Human Factors and Ergonomics Society, Inc., Vol. 2, pp. 1043-1047.

Lin, L., Isla, R., Doniz, K., Harkness, H., Vicente, K. J. and Doyle, D. J. (1998) 'Applying human factors to the design of medical equipment: Patient-controlled analgesia', Journal of Clinical Monitoring and Computing, Vol. 14, No. 4, pp. 253-263.

Lin, L., Vicente, K. J. and Doyle, D. J. (2001) 'Patient safety, potential adverse drug events, and medical device design: A human factors engineering approach', Journal of Biomedical Informatics, Vol. 34, No. 4, pp. 274-284.

Mackay, H., Carne, C., Beynon-Davies, P. and Tudhope, D. (2000) 'Reconfiguring the User: Using Rapid Application Development', Social Studies of Science, Vol. 30, No. 5, pp. 737-757.

Margolin, V. (1997) 'Getting to know the user', Design Studies, Vol. 18, No. 3, pp. 227-236.

Martin, J. L., Murphy, E., Crowe, J. A. and Norris, B. J. (2006) 'Capturing user requirements in medical device development: The role of ergonomics', Physiological Measurement, Vol. 27, No. 8, pp. R49R62. 
Reference to this paper should be made as follows: Shah, S.G.S. and Robinson, I. (2008) 'Medical device technologies: who is the user?', Int. J. Healthcare Technology and Management, Vol. 9, No. 2, pp.181-197. DOI: 10.1504/IJHTM.2008.017372 [Note: This is pre-published version of the paper]

MATCH (2006) 'MATCH: Multidisciplinary Assessment of Technology Centre for Healthcare.' Available at: http://www.match.ac.uk/ (Accessed 10 March 2006).

Miettinen, R. and Hasu, M. (2002) 'Articulating user needs in collaborative design: Towards an activity-theoretical approach', Computer Supported Cooperative Work, Vol. 11, No. 1-2, pp. 129151.

Mulholland, S. J., Packer, T. L., Laschinger, S. J., Lysack, J. T., Wyss, U. P. and Balaram, S. (2000) 'Evaluating a new mobility device: Feedback from women with disabilities in India', Disability and Rehabilitation, Vol. 22, No. 3, pp. 111-122.

Newapproach (2004) 'Directives \& Standards (on Medical devices: General, in vitro diagnostic and active implantable)', New Approach Standardisation in Europe. Available at: http://www.newapproach.org/Directives/Default.asp (Accessed 10 March 2006).

Nobel, J. J. (1996) 'Medical device accident reporting: does it improve patient safety?' In N. Pallikarakis, N. Anselmann and A. Pernice (Eds) Studies in Health Technology and Informatics, Vol. 28, Amsterdam: IOS Press, pp. 29-35.

Obradovich, J. H. and Woods, D. D. (1996) 'Users as designers: How people cope with poor $\mathrm{HCl}$ design in computer-based medical devices', Human Factors, Vol. 38, No. 4, pp. 574-592.

Poolton, J. and Ismail, H. (2000) 'New developments in innovation', Journal of Managerial Psychology, Vol. 15, No. 8, pp. 795-811.

Potter-Brotman, J. (1994) 'The new role of service in customer retention', Managing Service Quality, Vol. 4, No. 4, pp. 53-56.

Ritter, T. and Walter, A. (2003) 'Relationship-specific antecedents of customer involvement in new product development', International Journal of Technology Management, Vol. 26, No. 5/6, pp. 482501.

Rowley, J. (2000) 'From users to customers?' OCLC Systems \& Services, Vol. 16, No. 4, pp. 157-167.

Samore, M. H., Evans, R. S., Lassen, A., Gould, P., Lloyd, J., Gardner, R. M., Abouzelof, R., Taylor, C., Woodbury, D. A., Willy, M. and Bright, R. A. (2004) 'Surveillance of Medical Device-Related Hazards and Adverse Events in Hospitalized Patients', JAMA, Vol. 291, No. 3, pp. 325-334.

Samuelsson, K., Larsson, H., Thyberg, M. and Gerdle, B. (2001) 'Wheelchair seating intervention. Results from client-centered approach', Disability and Rehabilitation, Vol. 23, No. 15, pp. 677-682.

Shah, S. G. S. and Robinson, I. (2006) 'User Involvement in Medical Device Technology Development and Assessment: A Structured Literature Review', International Journal of Health Care Quality Assurance, Vol. 19, No. 6, pp. 500-515.

Shaw, B. (1985) 'The role of the interaction between the user and the manufacturer in medical equipment industry', R\&D Management, Vol. 15, No. 4, pp. 283-292.

Shaw, B. (1998) 'Innovation and new product development in the UK medical equipment industry', International Journal of Technology Management, Vol. 15, No. 3/4/5, pp. 433-445.

Small, S. D. (2004) 'Medical Device-Associated Safety and Risk: Surveillance and Stratagems', JAMA, Vol. 291, No. 3, pp. 367-370.

Staccini, P., Joubert, M., Quaranta, J.-F., Fieschi, D. and Fieschi, M. (2001) 'Modelling health care processes for eliciting user requirements: $A$ way to link a quality paradigm and clinical information system design', International Journal of Medical Informatics, Vol. 64, No. 2-3, pp. 129-142.

Stickle, M. S., Ryan, S., Rigby, P. J. and Jutai, J. W. (2002) 'Toward a comprehensive evaluation of the impact of electronic aids to daily living: Evaluation of consumer satisfaction'. Disability and Rehabilitation, Vol. 24, No.1-3, pp. 115-125.

Stone, R. and McCloy, R. (2004) 'Ergonomics in medicine and surgery', BMJ, Vol. 328, No. 7448, pp. 1115-1118.

Swissmedic (2001a) 'Guide to the regulation of medical devices. ' Bern, Switzerland, Swissmedic-Swiss Agency for Therapeutic Products. Available at: http://www.swissmedic.ch/md/files/leitf-e.html (Accessed 10 March 2006).

Swissmedic (2001b) 'Medical devices ordinance (Medizinprodukteverordnung MepV, SR 812.213) (English translation)', Bern, Switzerland, Swissmedic-Swiss Agency for Therapeutic Products. Available at: http://www.swissmedic.ch/md/pdf/mepv-e.pdf (Accessed 10 March 2006).

Swissmedic (2001c) 'Medical devices overview: Changes under the new therapeutic products legislation', Bern, Switzerland, Swissmedic-Swiss Agency for Therapeutic Products. Available at: http://www.swissmedic.ch/md/pdf/hmg-all-e.pdf (Accessed 10 March 2006). 
Reference to this paper should be made as follows: Shah, S.G.S. and Robinson, I. (2008) 'Medical device technologies: who is the user?', Int. J. Healthcare Technology and Management, Vol. 9, No. 2, pp.181-197. DOI: 10.1504/IJHTM.2008.017372 [Note: This is pre-published version of the paper]

Teeravarunyou, S. and Sato, K. (2001) 'User process based product architecture', in The World Congress on Mass Customization and Personalization, Hong Kong, October 1-2, pp. 1-10.

Therapeutic Goods Administration (1989) 'An overview of the new medical devices regulatory system: Australian medical devices guidelines', Therapeutic Goods Administration, Department of Health and Ageing, Commonwealth of Australia, Guidance Document No. 1, Version 1.6., pp. 1-14.

Therapeutic Goods Administration (2003) 'Medical devices', TGA News - The official newsletter of the Therapeutic Goods Administration, Vol. 42, November, pp. 3-4.

Thoren, M. (1996) 'Systems approach to clothing for disabled users: Why is it difficult for disabled users to find suitable clothing', Applied Ergonomics, Vol. 27, No. 6, pp. 389-396.

United Nations (1997) 'Production and distribution of assistive devices for people with disabilities. Part one: Regional review', New York, Economic and Social Commission for Asia and the Pacific, United Nations, Document No. ST/ESCAP/1774. Available at: http://www.dinf.ne.jp/doc/english/intl/z15/z15001p1/z1500101.htm (Accessed 10 March 2006).

Wai, K. and Siu, M. (2003) 'Users' creative responses and designers' roles', Design Issues, Vol. 19, No. 2, pp. 64-73.

Ward, J. R. and Clarkson, J. P. (2004) 'An analysis of medical device-related errors: prevalence and possible solutions', Journal of Medical Engineering \& Technology, Vol. 28, No. 1, pp. 2-21.

Woodside, A. G., Breaux, R. and Briguglio, E. (1998) 'Testing care-giver acceptance of new syringe technologies', International Journal of Technology Management, Vol. 15, No. 3/4/5, pp. 446-457.

World Health Organization (2003) 'Medical device regulations: Global overview and guiding principles', Geneva, World Health Organization.

\section{Author biographical notes:}

Syed Ghulam Sarwar Shah is Research Fellow in the Centre for the Study of Health and Illness, School of Social Sciences at Brunel University. He is medical doctor and has worked in the healthcare industry for several years. His research interests include user perspectives vis-à-vis medical device technologies, user involvement in medical device technology development and assessment, and health and safety of medical device users including exposure to electromagnetic fields (EMFs) from medical devices in clinical practice.

E-mail: Sarwar.Shah@brunel.ac.uk

Ian Robinson is Professor of Sociology in the School of Social Sciences and founder director of the Centre for the Study of Health and IIIness in the School at Brunel University. He has researched extensively on neurological illnesses, including multiple sclerosis and motor neurone diseases, and has focused particularly on user views and experiences in chronic diseases. He is also engaged in research on the social aspects of medical device technologies.

E-mail: lan.Robinson@brunel.ac.uk 